\title{
Application of Jigsaw Learning Method Using Play Money Learning Media to Improve Mathematics Learning Outcomes
}

\author{
Rina Eka Fitriani \\ SD Negeri 4 Mangin \\ rinaekafitriani89@gmail.com
}

\section{Article History}

received $3 / 12 / 2020$

revised $17 / 12 / 2020$

accepted 31/12/2020

\begin{abstract}
This study aims to improve mathematics learning outcomes about money in class III semester I SDN 4 Mangin, Karangrayung District, Grobogan Regency, 2017/2018 academic year through toy money media and the application of Jigsaw learning method. The research subjects were grade 3 students at SDN 4 Mangin, totaling 14 students. The research design is classroom action research consisting of two cycles. Each cycle consists of 2 meetings. Data collection techniques using evaluation in the form of assignments, worksheets and evaluation questions. While the data analysis includes qualitative data and quantitative data. Learning outcomes from the pre-cycle were obtained, from 14 students, only 5 students (36\%) had reached the mastery target with a minimum score of 65 . In the first cycle, classical completeness was $71 \%$. While in the second cycle of $100 \%$. These results indicate that the application of the Jigsaw method using toy money media can improve mathematics learning outcomes for grade 3 students at SDN 4 Mangin.
\end{abstract}

Keywords: learning outcomes, Jigsaw learning method

\begin{abstract}
Abstrak
Penelitian ini bertujuan untuk meningkatkan hasil belajar Matematika tentang uang di kelas III semester I SDN 4 Mangin, Kecamatan Karangrayung, Kabupaten Grobogan, Tahun Pelajaran 2017/2018 melalui media uang mainan dan penerapan metode pembelajaran Jigsaw. Subyek penelitian siswa kelas 3 SDN 4 Mangin yang berjumlah 14 siswa. Desain penelitian adalah penelitian tindakan kelas terdiri dari dua siklus. Masing-masing siklus terdiri dari 2 pertemuan. Teknik pengumpulan data dengan menggunakan evaluasi dalam bentuk Tugas, LKS dan Soal Evaluasi. Sedangkan analisis data meliputi data kualitatif dan data kuantitatif Hasil belajar dari pra siklus diperoleh, dari 14 siswa, hanya 5 siswa (36\%) yang sudah mencapai target ketuntasan dengan nilai minimal ketuntasan 65. Pada siklus I ketuntasan klasikal sebesar $71 \%$. Sedangkan pada siklus II sebesar $100 \%$. Hasil ini menunjukkan bahwa penerapan metode Jigsaw dengan menggunakan media uang mainan dapat meningkatkan hasil belajar matematika siswa kelas 3 SDN 4 Mangin.
\end{abstract}

Kata kunci: hasil belajar, metode pembelajaran Jigsaw

Social, Humanities, and Education Studies (SHEs): Conference Series https://jurnal.uns.ac.id/shes

p-ISSN 2620-9284

e-ISSN 2620-9292

This work is licensed under a Creative Commons Attribution-ShareAlike 4.0 International License. 


\section{PENDAHULUAN}

Dalam proses Belajar-Mengajar di kelas, takkan pernah lepas dari suatu masalah. Baik yang dirasakan oleh Guru maupun oleh siswa. Begitu pula pada proses Belajar-Mengajar siswa kelas III Semester I SD Negeri 4 Mangin, Kecamatan Karangrayung, Kabupaten Grobogan, Tahun Pelajaran 2017/2018 khususnya pada mata pelajaran Matematika. Kemampuan siswa dalam memahami materi pada mata pelajartan Matematika sangat kurang.

Gauss dalam (Ismadi,2011-2), mendefinisikan matematika adalah ratu dari ilmu pengetahuan dan aritmetika adalah ratu dari matematika. Susanto (2013:185), matematika merupakan salah satu disiplin ilmu yang dapat meningkatkan kemampuan berfikir dalam menyelesaikan permasalahan sehari-hari dan dalam dunia kerja. Dalam kurikulum pendidikan di Indonesia, mata pelajaran matematika perlu diberikan kepada peserta didik untuk membekali mereka melalui kemampuan berfikir logis, analistis, sistematis, kritis, kreatif, serta kemampuan bekerjasama. Namun secara umum, matematika merupakan pelajaran yang dianggap sulit dan tidak disukai oleh siswa. Hal itu terbukti dari nilai hasil belajar siswa SD Negeri 4 Mangin yang beberapa diantaranya masih dibawah KKM. Hasil belajar merupakan perubahan perilaku dari proses belajar yang telah terjadi. Seorang guru harus memperhatikan secara seksama supaya perubahan periaku tersebut dapat dicapai sepenuhnya dan menyeluruh oleh siswa. Gagne dalam (Anitah W,dkk,2014:2.19), menyebutkan lima tipe hasil belajar yang dapat dicapai oleh siswa 1) motor skills; 2) verbal information; 3) intelectual skills; 4) attitudes; dan 5) cognitive strategies.

Salah satu komponen yang harus digunakan dalam kegiatan pembelajaran untuk mencapai tujuan pembelajaran adalah metode mengajar. Metode yang dalam bahasa Inggris, method berarti cara yang apabila kita kaitkan dengan pembelajaran, adalah cara yang digunakan guru untuk membelajarkan siswanya. Syaiful Bahri Djamarah \& Winarno Surakhmad dalam (Fathurrohman dan Sutikno,2010:15), mengemukakan lima macam faktor yang mempengaruhi penggunaan metode mengajar, yaitu: 1. Tujuan dengan berbagai jenis dan fungsinya; 2. Anak didik dengan berbagai tingkat kematangannya; 3. Situasi berlainan keadaannya; 4. Fasilitas bervariasi secara kualitas dan kuantitasnya; 5. Kepribadian dan kompetensi guru yang berbeda-beda.

Pembelajaran adalah proses interaksi antar anak dengan anak, anak dengan sumber belajar, dan anak dengan pendidik (Daryanto, 2014:1). Sedangkan Darsono, 2000:24 (dalam Hamdani, 2011:23) pembelajaran adalah cara guru memberikan kesempatan kepada siswa untuk berfikir agar mengenal dan memahami sesuatu yang sedang dipelajari. Sehingga, pembelajaran adalah suatu usaha yang diberikan oleh guru kepada peserta didik untuk berinteraksi dengan peserta didik lain untuk mengetahui suatu hal baru melalui perantara sumber belajar.

Media merupakan salah satu faktor penentu keberhasilan pembelajaran. Melalui media, proses pembelajaran bisa lebih menarik dan menyenangkan. Aspek penting lainnya penggunaan media adalah membantu memperjelas pesan pembelajaran. Media pembelajaran selalu terdiri dari 2 unsur penting. Kedua unsur tersebut adalah unsur peralatan atau perangkat keras (hardware) dan unsur pesan yang dibawanya (message/software) (Anitah W, dkk,2014:6.6). Fungsi utama media pembelajaran, yaitu sebagai sarana bantu untuk mewujudkan situasi pembelajaran yang efektif. Peneliti harus menemukan cara bagaiman menggunakan media pembelajaran berupa uang mainan dan penerapan model pemnbelajaran Jigsaw untuk meningkatkan hasil belajar mata pelajaran matematika tentang uang, siswa kelas III Semester I SD Negeri 4 Mangin, Kecamatan Karangrayung, Kabupaten Grobogan, Tahun Pelajaran 2017/2018?

Hasil belajar adalah perubahan perilaku seseorang akibat belajar. Perubahan perilaku disebabkan karena mencapai penguasaan atas sejumlah bahan yang diberikan dalam proses belajar mengajar. Pencapaian itu didasarkan atas tujuan 
pengajaran yang telah ditetapkan. Hasilnya berupa perubahan dalam aspek kognitif, afektif maupun psikomotorik (Purwanto, 2011:46).

Berdasarkan masalah yang terjadi, tujuan dari penelitian ini adalah tercapai upaya guru dalam meningkatkan hasil belajar siswa tentang Uang pada mata Pelajaran Matematika di kelas III semester I SD Negeri 4 Mangin, Kecamatan Karangrayung, Kabupaten Grobogan, Tahun Pelajaran 2017/2018 melalui media pembelajaran yang berupa uang mainan dan penerapan model pembelajaran Jigsaw.

Penerapan metode Jigsaw untuk meningkatkan hasil belajar siswa, sebelumnya sudah dilakukan beberapa penelitian. Puji Ari Wibowo (2014) mendapatkan bahwa pembelajaran Matematika yang dikolaborasikan dengan metode Jigsaw dapat meningkatkan hasil belajar peserta didik secara efektif. Ridwan Antonius. (2016) menyimpulkan bahwa ada perbedaan hasil belajar antara siswa yang diberi pembelajaran Matematika menggunakan metode Jigsaw dibandingkan dengan cara konvensional metode eksperimen.

Dari uraian di atas, peneliti mencoba menyusun rumusan masalah sebagai berikut: Apakah melalui metode pembelajaran Jigsaw dapat meningkatkan hasil belajar mtematika materi uang pada siswa kelas III Semester I SD Negeri 4 Mangin Tahun Pelajaran 2017/2018? Adapun tujuan penelitian ini adalah untuk mengetahui peningkatan hasil belajar siswa tentang uang pada mata pelajaran Matematika di kelas III semester I SD Negeri 4 Mangin, Kecamatan Karangrayung, Kabupaten Grobogan, Tahun Pelajaran 2017/2018 melalui media pembelajaran yang berupa uang mainan dan penerapan model pembelajaran Jigsaw.

\section{METODE}

Penelitian ini adalah penelitian tindakan kelas (Classroom Action Research) dengan menerapkan metode pembelajaran Jigsaw dengan media uang mainan. Menurut Kurt Lewin dalam Kunandar (2011: 42) penelitian tindakan kelas ini terdiri dari empat tahapan dasar yaitu perencanaan (planning), pelaksanaan (acting), pengamatan (observing) dan refleksi (reflecting).

Penelitian ini dilaksanakan di SD Negeri 4 Mangin yang beralamat di Dukuh Pulo, Desa Mangin Kecamatan Karangrayung Kabupaten Grobogan. Penelitian ini dilaksanakan selama empat bulan, yaitu bulan September sampai dengan Desember 2017. Subjek penelitian ini adalah siswa kelas III Semester I SD Negeri 4 Mangin berjumlah 14 siswa, jumlah siswa laki-laki sebanyak 6 siswa dan 8 siswa perempuan. Pada tindakan siklus I pertemuan pertama dilaksanakan pada hari Kamis tanggal 12 Oktober 2017, sedangkan pertemuan kedua dilaksanakan pada hari Kamis tanggal 19 Oktober 2017. Pada tindakan siklus II pertemuan pertama dilaksanakan pada hari Rabu tanggal 8 November 2017, sedangkan pertemuan kedua dilaksanakan pada hari Kamis tanggal 16 November 2017.

Teknik pengumpulan data dengan teknik tes, observasi, dan dokumentasi. Teknik analisis data yang digunakan pada penelitian ini untuk mengolah dan menganalisis data hasil belajar siswa. Hal-hal yang dianalisis terkait dengan hasil belajar siswa adalah nilai hasil belajar siswa, rata-rata kelas, dan persentase tuntas belajar klasikal..

\section{HASIL DAN PEMBAHASAN}

Temuan penelitian yang menjadi fokus perbaikan yang dihimpun selama pelaksanaan pembelajaran dapat dipaparkan adalah sebagai berikut:

Sebelum dilakukan perbaikan pembelajaran atau pra siklus didapat data dari 14 siswa, hanya 5 siswa (36\%) yang sudah mencapai target ketuntasan dengan nilai minimal ketuntasan 65 dan 9 siswa (64\%) belum lulus KKM.

Setelah guru melaksanakan pembelajaran siklus I mata pelajaran matematika materi "Uang". Peneliti masih mengalami permasalahan, setelah mengadakan 
evaluasi, dari 14 siswa terdapat 10 siswa (71\%) yang sudah tuntas dan 4 siswa (29\%) yang belum tuntas dengan nilai ketuntasan minimal 65. Dalam hal ini, dapat diperoleh kesimpulan sementara bahwa proses pembelajaran sudah dua arah. Guru memberi kesempatan bertanya pada siswa. Namun masih terdapat siswa yang tidak memperhatikan penjelasan guru. Hal ini disebabkan penyampaian materi oleh guru dianggap kurang menarik perhatian siswa sehingga masih banyak yang belum mengerti.

Selanjutnya, kesimpulan sementara tersebut dipergunakan sebagai dasar untuk menyusun langkah perbaikan siklus II.

Berdasarkan hasil refleksi terhadap perbaikan pembelajaran Siklus I, maka peneliti menyusun rencana perbaikan pembelajaran berupa prosedur kerja yang dilaksanakan dalam proses pembelajaran dikelas yang terdiri atas perencanaan, pelaksanaan, pengamatan, dan refleksi.

Setelah guru melaksanakan pembelajaran siklus I mata pelajaran matematika dengan materi "Uang". Dalam penelitian, peneliti menggunakan media pembelajaran berupa uang mainan, dan dengan metode yang bervariasi, menyebabkan adanya peningkatan hasil belajar. dari 14 siswa, semua tuntas dengan nilai ketuntasan minimal 65. Dalam hal ini, dapat diperoleh kesimpulan sementara bahwa proses pembelajaran sudah dua arah. Guru memberi kesempatan bertanya pada siswa. Namun masih terdapat siswa yang tidak memperhatikan penjelasan guru.

Tabel 1. Hasil Evaluasi Mata Pelajaran Matematika sebelum Perbaikan Pembelajaran/prasiklus

\begin{tabular}{ccccc}
\hline No & Rentang Nilai & Jumlah & Prosentase & Keterangan \\
\hline 1 & $45-54$ & 2 & $14 \%$ & Tidak Tuntas \\
2 & $55-64$ & 7 & $50 \%$ & Tidak Tuntas \\
3 & $65-74$ & 0 & $0 \%$ & - \\
4 & $75-84$ & 4 & $29 \%$ & Tuntas \\
5 & $85-94$ & 1 & $7 \%$ & Tuntas \\
6 & $95-100$ & 0 & $0 \%$ & - \\
& Jumlah & 14 & $100 \%$ & \\
\hline
\end{tabular}

Berdasarkan tabel diatas dapat dilihat hasil evaluasi mata pelajaran Matematika dengan materi "Uang" kelas III Semester I SD Negeri 4 Mangin, Kec. Karangrayung, Kab. Grobogan. Sebelum kegiatan perbaikan pembelajaran, dari total 14 siswa, yang mendapat nilai 45-54 berjumlah 2 siswa, nilai 55-64 berjumlah 7 siswa, nilai 65-74 bejumlah 0 siswa, nilai 75-84 berjumlah 4 siswa, nilai 85-94 berjumlah 1 siswa, nilai 95100 berjumlah 0 siswa.

Tabel 2. Hasil Evaluasi Mata Pelajaran Matematika Siklus 1

\begin{tabular}{ccccc}
\hline No & Rentang Nilai & Jumlah & Prosentase & Keterangan \\
\hline 1 & $45-54$ & 0 & $0 \%$ & - \\
2 & $55-64$ & 4 & $29 \%$ & Tidak Tuntas \\
3 & $65-74$ & 0 & $0 \%$ & - \\
4 & $75-84$ & 5 & $36 \%$ & Tuntas \\
5 & $85-94$ & 3 & $21 \%$ & Tuntas \\
6 & $95-100$ & 2 & $14 \%$ & Tuntas \\
& Jumlah & 14 & $100 \%$ & \\
\hline
\end{tabular}

Berdasarkan tabel diatas dapat dilihat hasil evaluasi mata pelajaran Matematika dengan materi "Uang" kelas III Semester I SD Negeri 4 Mangin, Kec. Karangrayung, Kab. Grobogan. Sebelum kegiatan perbaikan pembelajaran, dari total 14 siswa, yang 
mendapat nilai 45-54 berjumlah 0 siswa, nilai 55-64 berjumlah 4 siswa, nilai $65-74$ bejumlah 0 siswa, nilai 75-84 berjumlah 5 siswa, nilai 85-94 berjumlah 3 siswa, nilai 95100 berjumlah 2 siswa.

Tabel 3. Hasil Evaluasi Mata Pelajaran Matematika Siklus 2

\begin{tabular}{ccccc}
\hline No & Rentang Nilai & Jumlah & Prosentase & Keterangan \\
\hline 1 & $45-54$ & 0 & $0 \%$ & - \\
2 & $55-64$ & 0 & $0 \%$ & - \\
3 & $65-74$ & 0 & $0 \%$ & - \\
4 & $75-84$ & 3 & $21 \%$ & Tuntas \\
5 & $85-94$ & 7 & $50 \%$ & Tuntas \\
6 & $95-100$ & 4 & $29 \%$ & Tuntas \\
& Jumlah & 14 & $100 \%$ & \\
\hline
\end{tabular}

Berdasarkan tabel diatas dapat dilihat hasil evaluasi mata pelajaran Matematika dengan materi "Uang" kelas III Semester I SD Negeri 4 Mangin, Kec. Karangrayung, Kab. Grobogan. Sebelum kegiatan perbaikan pembelajaran, dari total 14 siswa, yang mendapat nilai $45-54$ berjumlah 0 siswa, nilai $55-64$ berjumlah 0 siswa, nilai $65-74$ bejumlah 0 siswa, nilai 75-84 berjumlah 3 siswa, nilai 85-94 berjumlah 7 siswa, nilai 95100 berjumlah 4 siswa.

Berdasarkan tabel I, II, dan III hasil perolehan data mata pelajaran Matematika dengan materi "Uang" kelas III Semester I SD Negeri 4 Mangin, Kec. Karangrayung, Kab. Grobogan, dapat kita lihat peningkatan hasil belajar siswa. Siswa yang tuntas adalah siswa yang mendapat nilai $65 \mathrm{ke}$ atas. Dalam kegiatan pembelajaran sebelum diadakan perbaikan, ada 5 siswa dari 14 siswa atau 36\% yang mengalami ketuntasan. Pada perbaikan siklus I meningkat menjadi 10 siswa dari 14 siswa atau $71 \%$ yang mengalami ketuntasan. Pada perbaikan siklus II kembali meningkat dari 14 siswa, seluruh siswa mengalami ketuntasan atau $100 \%$ sehingga perbaikan pembelajaran cukup pada siklus II karena semua siswa telah mengalami ketuntasan. Apabila hasil perolehan data tersebut disajikan dalam tabel, maka dapat kita lihat pada tabel IV sebagai berikut

Tabel 4. Peningkatan Ketuntasan Hasil Belajar

\begin{tabular}{cccccccc}
\hline & & \multicolumn{2}{c}{ Pra siklus } & \multicolumn{2}{c}{ Siklus I } & \multicolumn{2}{c}{ Siklus II } \\
No & Ketuntasan & Jumlah & $\%$ & Jumlah & $\%$ & Jumlah & $\%$ \\
\hline 1 & Tuntas & 5 & 36 & 10 & 71 & 14 & $100 \%$ \\
2 & Belum tuntas & 9 & 64 & 4 & 29 & - & - \\
\hline
\end{tabular}

Dengan melihat data di atas dapat diuraikan sebagai berikut :

a. Sebelum perbaikan pembelajaran siswa yang tuntas hanya 5 siswa dari 14 siswa $(36 \%)$

b. Pada siklus I siswa yang tuntas 10 siswa dari 14 siswa $(71 \%)$

c. Pada siklus II siswa yang tuntas 14 siswa dari 14 siswa (100\%)

Sedangkan siswa yang belum tuntas adalah sebagai berikut :

a. Sebelum perbaikan pembelajaran siswa yang belum tuntas 9 siswa dari 14 siswa $(64 \%)$

b. Pada siklus I siswa yang belum tuntas 4 siswa dari 14 siswa $(71 \%)$

c. Pada siklus II siswa yang belum tuntas 0 siswa dari 0 siswa $(0 \%)$ 
Apabila ketuntasan hasil belajar mata pelajaran Matematika dengan materi “Uang” kelas III Semester I SD Negeri 4 Mangin, Kec. Karangrayung, Kab. Grobogan disajikan dalam diagram, maka akan terlihat pada diagram sebagai berikut:

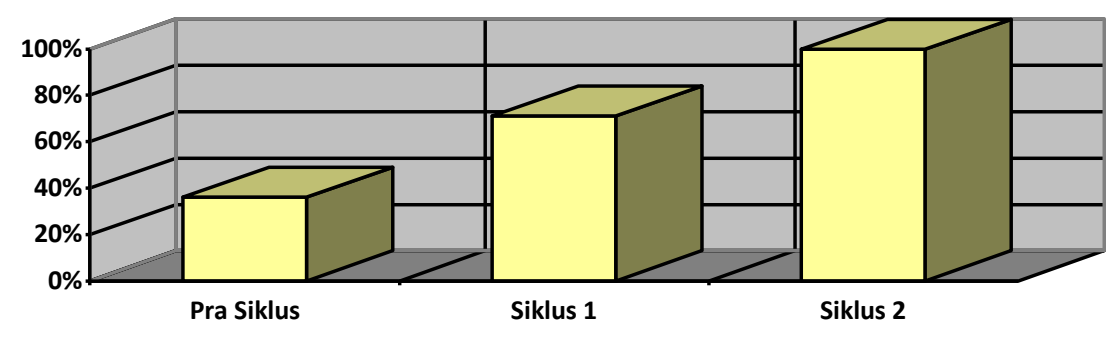

Gambar 4 : Grafik ketuntasan Hasil Belajar Matematika

Berdasarkan hasil yang diperoleh dari sebelum perbaikan (pra siklus), perbaikan Siklus I dan II telah membuktikan bahwa dalam keberhasilan dalam proses pembelajaran dipengaruhi oleh banyak hal. Diantaranya adalah faktor guru. Kemampuan Guru dalam mengelola proses pembelajaran sangat mempengaruhi tingkat hasil belajar siswa. Kemampuan guru tersebut diantaranya adalah cara memilih strategi, media yang digunakan, serta metode yang diterapkan. Kemampuankemampuan tersebut berpengaruh besar pada hasil belajar siswa.

Proses pembelajaran pada siklus I masih terkendala oleh beberapa hal. Misalnya kurangnya penggunaan media pembelajaran berupa uang mainan secara optimal oleh guru. Sehingga pemahaman siswa pada materi ajar masih kurang/rendah.

Diskusi kelompok kurang menarik bagi siswa. Siswa terlihat kurang antusias dan bosan. Hal ini karena kurangnya interaksi antara guru dengan siswanya sehingga siswa kurang mengerti pada penjelasan guru.

Hasil analisis penilaian menunjukkan bahwa masih kurangnya pemahaman siswa pada materi pelajaran. Hal ini dapat kita lihat dari 14 siswa, yang sudah memenuhi kriteria ketuntasan adalah 10 siswa atau baru $71 \%$. Dengan demikian, guru merencanakan perbaikan pembelajaran siklus II.

Pelaksanaan perbaikan pembelajaran siklus II terbilang lancar. Guru merancang proses pembelajaran lebih matang. Alat peraga berupa uang mainan digunakan secara optimal untuk kelompok-kelompok siswa yang masing-masing terdiri dari 2 siswa.

Dari hasil analisis penilaian menunjukkan bahwa hasil penilaian pada perbaikan pembelajaran siklus II lebih baik dari pada hasil penilaian perbaikan pembelajaran siklus I. Keberhasilan ini disebabkan karena penggunaan media pembelajaran dalam proses belajar yang lebih efektif dan optimal serta dengan penjelasan metode tugas dan kelompok yang lebih efektif dan menarik perhatian siswa. Sehingga siswa-siswa akan lebih aktif belajar dan lebih meningkatkan pemahaman terhadap materi pelajaran. Dengan demikian seperti yang diuraikan pada kajian teori bahwa pembelajaran akan menyenangkan dan bermakna apabila dalam proses belajar, guru lebih terampil dalam menggunakan media dan metode pembelajaran yang sesuai dengan materi ajar. dan lebih menarik minat siswa. Sebagai bukti bahwa pembelajaran dikatakan berhasil adalah adanya hasil evaluasi yang mencapai ketuntasan minimal yang telah ditetapkan untuk pelajaran Matematika. Hasilnya dapat kita lihat dalam tes formatif siswa yang dilaksanakan oleh guru setelah proses pembelajaran selesai. 


\section{SIMPULAN}

Berdasarkan keseluruhan hasil dalam perbaikan pembelajaran yang telah dilaksanakan tersebut, maka ditarik kesimpulan sebagai berikut:: a. Dari penelitian yang dilakukan dengan metode Jigsaw dengan media uang mainan dapat meningkatkan hasil belajar siswa dengan dibuktikan jumlah siswa yang lulus KKM berangsur-angsur naik dan pada siklus II jumlah tersebut telah memenuhi target yang telah ditetapkan yaitu 100\% siswa dapat lulus KKM. b. Perhatian guru harus adil, sehingga seluruh siswa mendapat kesempatan yang sama c. Selain itu, perlu adanya praktik langsung sehingga siswa dapat memahami maksud dan tujuan pembelajaran d. Terdapat perbedaan hasil belajar siswa, dimana siklus 1 sejumlah $71 \%$ siswa lulus KKM dan siklus 2 sejumlah 100\% sudah lulus KKM. e. Diperlukan kesabaran dan ketelitian guru dalam proses belajar mengajar.

Dengan adanya penelitian penggunaan Metode Jigsaw dan media uang mainan, guru hendaknya dapat menjadikan metode dan media tersebut sebagai alternatif proses pembelajaran di dalam kelas. Guru harus lebih kreatif dalam merancang pembelajaran di kelas yang aktif, efektif, dan menyenangkan. Dalam pembelajaran siswa hendaknya bisa menumbuhkan motivasi dan minat belajar, sehingga tujuan pembelajaran dapat tercapai secara optimal. Sekolah hendaknya memberikan sarana dan prasarana, fasilitas serta motivasi bagi guru yang akan menerapkan berbagai macam metode dan media yang akan digunakan sehingga pembelajaran berjalan optimal.

\section{DAFTAR PUSTAKA}

Ali, Hamdani (2012). Teori Motivasi Psikologi Pendidikan. Skripsi: Universitas Islam Indonesia Yogyakarta

Anitah W. Sri. (2014). Strategi Pembelajaran di SD. Jakarta: Universitas Terbuka.

Ari, Wibowo Puji. (2014). Penerapan Metode Pembelajaran Jigsaw di SD. Grobogan: SD Negeri 1 Tambirejo.

Daryanto. (2014). Pendekatan Pembelajaran Saintifik Kurikulum 2013. Yogyakarta: Gava Media

Fathurrohman. Pupuh, M. Sobry Sutikno. (2010). Strategi Belajar Mengajar. Bandung. PT. Refika Aditama

Ismadi, Janu. (2012). Belajar Matematika Kini Jadi Mudah. Jakarta: Multi Kreasi Satudelapan.

Purwanto. (2011). Evaluasi Hasil Belajar. Yogyakarta: Pustaka Belajar.

Ridwan A. (2016). Peningkatan Hasil Belajar IPA Dengan Penggunaan Metode Pembelajaran Jigsaw Pada Materi Pernapasan di SD Negeri 4 mangin. Grobogan: SD Negeri 4 mangin

Susanto, Ahmad. (2013). Teori Belajar dan Pembelajaran di Sekolah Dasar. Jakarta: PT Kharisma Putra Utama.

Sutirman. (2013). Media dan Model-model Pembelajaran Inovatif. Yogyakarta: Graha IImu. 